\title{
Message from the 2016 Program Chair
}

\author{
L. H. Mortensen ${ }^{1}$
}

Published online: 9 November 2016

(C) International Association of Medical Science Educators 2016

Dear Friends and Colleagues,

It is with great enthusiasm that the Program Committee for the 20th annual meeting of the International Association of Medical Science Educators (IAMSE), held in Leiden, The Netherlands, on June 4-7, 2016, presents these conference proceedings. This year's meeting drew more than 400 registrants from health profession schools and academic associations from around the world who engaged in lively and collegial discussions centered around the theme of "Learning Assessment: Connecting Health Science and Clinical Competence."

This issue of Medical Science Educator presents to you, our readers, a compilation of plenary speaker presentations in addition to the abstracts from our meeting's oral and poster submissions. The mission of IAMSE is to advance health profession education through teacher development and to ensure that the teaching and learning of medical science continues to be firmly grounded in foundational sciences and the best practices of teaching. This year's meeting successfully carried that mission through its offerings of timely and innovative Pre-conference Workshops, Faculty Development Courses, Plenary Sessions, Concurrent Focus Sessions, Poster Viewing Sessions, and Oral Presentations. Recipients of the IAMSE Master Scholar, Master Teacher, Student Travel, Oral Presentation, and Poster Presentation awards were our association's visionary champions. Future education leaders participated in our Essential Skills in Medical Education (ESME) Program and Educational Scholarship Fellowship Program.

IAMSE's members are international pioneers in health education; the work presented in this issue is a consistent testament to their aspiration of educational innovation and best practice achievement. We hope they embolden and motivate you in your own academic efforts. Please join us for our next annual meeting on June 10-13, 2017, in Burlington, VT, USA. We look forward to seeing you there!

Luke H Mortensen

Chair, 2016 Program Planning Committee
L. H. Mortensen

lmortensen@AACOM.org

1 American Association of Colleges of Osteopathic Medicine, Chevy Chase, MD, USA 